\title{
Cost and Income from Bottle Gourd Production in Meerut District of Western Uttar Pradesh
}

\author{
Krishna Kant $^{1 *}$, Tankit Kumar ${ }^{1}$ and J. P. Singh ${ }^{2}$ \\ ${ }^{1}$ Department of Agricultural Economics, Project coordinator (Program manager) in PANI \\ Sansthan Ayodhya, India \\ ${ }^{2}$ Department of Agricultural Economics in NDUAT Kumarganj Ayodhya, India \\ *Corresponding author
}

Keywords

Bottle Gourd

Production,

Vegetable

cultivation

Article Info

Accepted:

22 January 2021

Available Online:

10 February 2021
Vegetable cultivation plays an important role in the agricultural economy of India. Small and marginal farmers of India grow vegetable for generating income and increasing nutrient in the diet of people. Bottle gourd are the crucial vegetable crops grown by farmers in Meerut. On the basis of primary data to know cost of cultivation, Profit and input output ratio of bottle gourd cultivation. The purposive sampling was used to select districts and villages on the basis of highest area under these crops random sampling technique was used to select the 100 farmers and categorized under marginal small and medium farmers. Study concluded that an average cost of cultivation of bottle gourd per hectare came to Rs. 111613.00 and Per hectare cost of cultivation was highest (113046.00) on medium farms, mainly due to maximum investment on working capital. Costs and income of bottle gourd production per hectare average yield was calculated as 105.10 quintal per hectare and Per hectare gross income was highest on medium farms due to higher investment on H.Y.V. of seeds resulted higher productivity.

\section{Introduction}

India is the second largest producer of vegetables in the world next to China with area and production of 162.90 million hectare and 268.285 million tonnes and Uttar Pradesh has an important place in area and production with $14.52 \mathrm{~m}$ ha and 427.81 thousand tonnes in bottle guard (year 2017-18) and also Meerut district occupy a crucial place in bottle guard area and production with. $49 \mathrm{~m}$ ha and 14.21 thousand tonnes (year 2016-17) (Anonymous, 2018). The vegetable cultivation is preponderance of small and marginal farmers and also family labours were done all the operation of vegetable cultivation. Vegetables are the most important component of a balanced diet and provide health security to people by supplying nutrition through it. Now-a-days consumer's preferences have also shifted away from cereals and moved towards vegetables for balanced diet (Mittal, 2006). While, vegetable cultivation is facing the challenge of input output relationship. Therefore, an analysis at the farm level is desirable to get a clear 
understanding of the existence of gap between actual and potential output of agriculture crop in different regions. It is stated in the literature that the ratio between the actual and potential output is the measure of benefit cost ratio of a farm/farmer and the various socioeconomic characteristics of the farmers and other geographical (ecological) factors determine the variations in the efficiency level of farmers.

\section{Materials and Methods}

The district Meerut was selected purposively to avoid the operational inconvenience of the investigator. Out of twelve blocks of selected district, one block namely Kharkoda having highest area under bottle gourd crop was selected purposively. A list of all the villages falling under selected block was prepared and arranged in ascending order according to area covered by bottle gourd crop therefore; five villages were selected randomly from the list. A separate list of bottle gourd growers of selected five villages was prepared along with their size of holdings. Thus, the farm holding categorized into three size groups i.e. (1) Marginal (below 1.0 hectare), (2) Small (1.0 to 2.0 ha.) and (3) Medium (2.0 to 4.0 ha.) from this list a sample of hundred respondents were selected following the proportionate random sampling technique (Table 1).

\section{Tabular analysis}

Tabular analysis was used to compare the different parameters among marginal, small and medium size groups of the farmers. Cropwise costs and returns etc. were computed and presented in tabular forms. In this computation weighted average were used.

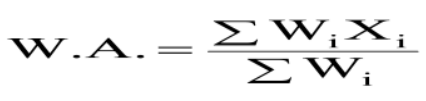

Where,

$$
\begin{array}{ll}
\mathrm{W} . \mathrm{A} . & =\text { Weighted average } \\
\mathrm{Xi} & =\text { Variable } \\
\mathrm{Wi} & =\text { Weight of variable }
\end{array}
$$

\section{C.A.C.P cost concept}

Cost $A_{1}=A L L$ The variable costs excluding family labour cost and including depreciation. The items covered in cost A1 was

1. Cost of hired human labour.

2. Cost of hired bullock labour.

3. Cost of owned bullock labour.

4. Cost of owned machinery.

5. Cost of hired machinery.

6. Cost of fertilizer.

7. Cost of manure.

8. Cost of seed (owned /purchased)

9. Cost of plant protection chemicals.

10. Irrigation charges (both owned and hired tube well, pumping sets etc.)

11. Canal water charges.

12. Land revenue, ceases and other taxes.

13. Depreciation of farm machinery, equipment and farm buildings.

14. Interest on owned working capital.

15. Interest payment on crop loan.

16. Miscellaneous expenses.

Cost $A_{2}=$ Cost $A_{1}+$ Rent paid for Leased in land

Cost $\mathrm{B}_{1}=$ Cost $\mathrm{A}_{1}+$ Interest on owned fixed capital assets excluding land

Cost $\mathrm{B}_{2}=$ Cost $\mathrm{B}_{1}+$ Rental value of own land (net of land revenue) + Rent paid for leased in land

Cost $\mathrm{C}_{1}=$ Cost $\mathrm{B}_{1}+$ Imputed value of family labour

Cost $\mathrm{C}_{2}=$ Cost $\mathrm{B}_{2}+$ Imputed value of family labour

Cost $\mathrm{C}_{2} *=$ Cost $\mathrm{C}_{2}$ was estimated by taking 
into account statutory minimum or actual wage rate, whichever is higher.

Cost $\mathrm{C}_{3}=$ Cost $\mathrm{C}_{2} *+10$ percent of $\operatorname{cost} \mathrm{C}_{2} *$ on account of managerial function

\section{Performed by the farmer}

Total cost of production was estimated on per quintal basis.

\section{Results and Discussion}

Per hectare costs on various input factors in bottle gourd production were worked out. The details of input costs are shown in table 2 indicate that on an average cost of cultivation of bottle gourd per hectare came to Rs. 111613.00. The cost of cultivation was maximum on medium farms (Rs.113046.00) followed by small farms (Rs. 111943.00) and marginal farms (Rs. 109850.00). Per hectare cost of cultivation was highest (113046.00) on medium farms, mainly due to maximum investment on working capital compared to the small and marginal farms.

On an average the study further reveals that major components on which maximum cost was incurred being 23.46 per cent on human labour followed by plant protection charges 12.43 per cent, manures and fertilizer 7.95 per cent, seed 8.65 per cent, irrigation 3.97 percent, machinery charges 2.39 per cent and bullock labour 0.36 per cent.

A similar trend indicated on all categories of sample farms. The cost incurred on interest on working capital, rental value of land, interest on fixed capital and 13\% managerial cost of sub-total was calculated as 1.23, 22.04, 7.05 and 11.50 per cent of total costs. The maximum share among these costs was rental value of owned land being 22.04 per cent of total cost per hectare.
Costs and income of bottle gourd production per hectare yield was calculated as 97.50, 104.80 and 113.00 quintal and average yield 105.10 quintal per hectare. Gross returns were calculated as maximum in medium farms Rs. 201140.00 followed by small farms Rs. 183400.00, marginal farms Rs. 70625.00 and observed gross return Rs. 184976.00, net income per hectare over cost $a+b+c$ was found highest in medium farms Rs. 113046.00 and lowest marginal farm Rs. 109850.00 and small farms Rs. 111943.00, net income over cost $\mathrm{C}_{1}$ medium farm is Rs. 126399.00, followed by small farm Rs. 108835.00 and marginal farms Rs. 97413.00 respectively and net return over cost $C_{2}$ is highest medium farm Rs.101099.00 followed by small farms Rs. 84435.00 and marginal farms Rs. 73413.00 , the B.C ratio found highest in bottle gourd crop medium farms 1: 1.77 followed by small farms $1: 1.63$ and marginal farms 1:1.55 respectively. Incomes from bottle gourd production were calculated and are given in Table 3. Per hectare gross income was observed maximum under medium farms i.e., Rs. 201140.00 followed by small farms (Rs. 183400.00) and marginal farms (Rs. 170625.00), respectively. Per hectare gross income was highest on medium farms due to higher investment on H.Y.V. of seeds resulted higher productivity. On an overall average, gross income came to Rs. 184976.00 whereas net income was Rs. 73363.00 per hectare. Overall average, family labour income, farm investment income and farm business income were worked out to be Rs. 102194.00, Rs. 118679.00 and Rs. 134670.00 per hectare, cost of production per quintal of bottle gourd was computed to be Rs. 1127.00, Rs. 1068.00, and 1001.00 on marginal, small and medium farms, with an average of Rs. 1062.00. Average input-output ratio on cost $A_{1}$, cost $B_{1}$, cost $B_{2}$, cost $C_{1}$, cost $\mathrm{C}_{2}$ and cost $\mathrm{C}_{3}$ were worked out and came to $1: 3.67,1: 3.17,1: 2.23,1: 2.49,1: 1.87$ and $1: 1.65$, respectively. 
Table.1 Total households and number of households selected under different size group of farms from sample villages

\begin{tabular}{|c|c|c|c|c|c|c|c|c|}
\hline \multirow{3}{*}{$\begin{array}{l}\text { Name } \\
\text { of village }\end{array}$} & \multicolumn{8}{|c|}{ Size-groups of farm } \\
\hline & \multicolumn{2}{|c|}{$\begin{array}{c}\text { Marginal } \\
\text { (Below 1.0) }\end{array}$} & \multicolumn{2}{|c|}{$\begin{array}{c}\text { Small } \\
(1.0-2.0)\end{array}$} & \multicolumn{2}{|c|}{$\begin{array}{c}\text { Medium } \\
(2.0-4.0)\end{array}$} & \multicolumn{2}{|c|}{ Total } \\
\hline & $\mathbf{P}$ & $\mathbf{S}$ & $\mathbf{P}$ & $\mathbf{S}$ & $\mathbf{P}$ & $\mathbf{S}$ & $\mathbf{P}$ & $\mathbf{S}$ \\
\hline Bijoli & & & & & & & & \\
\hline Dadri & & & & & & & & \\
\hline Ataula & & & & & & & & \\
\hline Nalpur & & & & & & & & \\
\hline Panchi & & & & & & & & \\
\hline Total & & & & & & & & \\
\hline
\end{tabular}

$\mathrm{P}=$ Total number of households, $\mathrm{S}=$ Selected number of households

Table.2 Per hectare input cost on different size of sample farm of Bottle gourd (Rs./ha)

\begin{tabular}{|c|c|c|c|c|c|}
\hline \multirow{2}{*}{$\begin{array}{l}\text { S. } \\
\text { No. }\end{array}$} & \multirow{2}{*}{$\begin{array}{l}\text { Components of } \\
\text { investment }\end{array}$} & \multicolumn{4}{|c|}{ Cost imputed to various components } \\
\hline & & $\begin{array}{c}\text { Marginal below } \\
1 \text { ha }\end{array}$ & $\begin{array}{c}\text { Small 1-2 } \\
\text { ha }\end{array}$ & $\begin{array}{c}\text { Medium 2-4 } \\
\text { ha }\end{array}$ & $\begin{array}{l}\text { Overall } \\
\text { average }\end{array}$ \\
\hline 1. & Human labour & $\begin{array}{c}24296.00 \\
(22.11)\end{array}$ & $\begin{array}{r}28126.00 \\
(25.12)\end{array}$ & $\begin{array}{c}26146.00 \\
(23.12)\end{array}$ & $\begin{array}{l}26190.00 \\
(23.46)\end{array}$ \\
\hline a. & Family labour & $\begin{array}{l}22442.00 \\
(20.42)\end{array}$ & $\begin{array}{c}19638.00 \\
(17.54)\end{array}$ & $\begin{array}{c}5892.00 \\
(5.26)\end{array}$ & $\begin{array}{c}15991.00 \\
(14.32)\end{array}$ \\
\hline b. & Hired labour & $\begin{array}{c}1854.00 \\
(1.68)\end{array}$ & $\begin{array}{l}8488.00 \\
(7.58)\end{array}$ & $\begin{array}{l}20254.00 \\
(18.09)\end{array}$ & $\begin{array}{c}10199.00 \\
(9.13)\end{array}$ \\
\hline 2. & Bullock labour & $\begin{array}{l}652.00 \\
(0.59)\end{array}$ & $\begin{array}{c}382.00 \\
(.34)\end{array}$ & $\begin{array}{l}178.00 \\
(0.15)\end{array}$ & $\begin{array}{l}404.00 \\
(0.36)\end{array}$ \\
\hline 3. & Machinery charges & $\begin{array}{c}2748.00 \\
(2.50)\end{array}$ & $\begin{array}{c}2905.00 \\
(2.59)\end{array}$ & $\begin{array}{c}2364.00 \\
(2.11)\end{array}$ & $\begin{array}{c}2672.00 \\
(2.39)\end{array}$ \\
\hline 4. & Seed & $\begin{array}{l}7554.00 \\
(6.87)\end{array}$ & $\begin{array}{l}8152.00 \\
(7.28)\end{array}$ & $\begin{array}{r}9684.00 \\
(8.65)\end{array}$ & $\begin{array}{c}8463.00 \\
(7.58)\end{array}$ \\
\hline 5. & Manure and fertilizer & $\begin{array}{c}8577.00 \\
(7.80)\end{array}$ & $\begin{array}{l}8825.00 \\
(7.88)\end{array}$ & $\begin{array}{r}9242.00 \\
(8.25)\end{array}$ & $\begin{array}{l}8881.00 \\
(7.95)\end{array}$ \\
\hline 6. & Irrigation & $\begin{array}{c}4810.00 \\
(4.37)\end{array}$ & $\begin{array}{c}4658.00 \\
(4.16)\end{array}$ & $\begin{array}{c}3848.00 \\
(3.43)\end{array}$ & $\begin{array}{c}4439.00 \\
(3.97)\end{array}$ \\
\hline 7. & Plant protection & $\begin{array}{c}12849.00 \\
(11.69)\end{array}$ & $\begin{array}{c}13527.00 \\
(12.08)\end{array}$ & $\begin{array}{c}15248.00 \\
(13.62)\end{array}$ & $\begin{array}{l}13875.00 \\
(12.43)\end{array}$ \\
\hline 8. & Total working capital & $\begin{array}{l}61486.00 \\
(55.97)\end{array}$ & $\begin{array}{c}66575.00 \\
(59.47)\end{array}$ & $\begin{array}{l}66710.00 \\
(59.59)\end{array}$ & $\begin{array}{l}64924.00 \\
(58.16)\end{array}$ \\
\hline 9. & $\begin{array}{l}\text { Interest on working } \\
\text { capital }\end{array}$ & $\begin{array}{c}1287.00 \\
(1.17)\end{array}$ & $\begin{array}{c}1414.00 \\
(1.26)\end{array}$ & $\begin{array}{c}1418.00 \\
(1.26)\end{array}$ & $\begin{array}{c}1373.00 \\
(1.23)\end{array}$ \\
\hline 10. & Rental value of land & $\begin{array}{l}24000.00 \\
(21.84)\end{array}$ & $\begin{array}{c}24500.00 \\
(21.88)\end{array}$ & $\begin{array}{l}25300.00 \\
(22.60)\end{array}$ & $\begin{array}{c}24600.00 \\
(22.04)\end{array}$ \\
\hline 11. & Interest on fixed capital & $\begin{array}{l}10439.00 \\
(9.50)\end{array}$ & $\begin{array}{c}6576.00 \\
(5.87)\end{array}$ & $\begin{array}{l}6613.00 \\
(5.90)\end{array}$ & $\begin{array}{r}7876.00 \\
(7.05)\end{array}$ \\
\hline 12. & Sub-total & $\begin{array}{l}97212.00 \\
(88.49)\end{array}$ & $\begin{array}{l}99065.00 \\
(88.49)\end{array}$ & $\begin{array}{c}100041.00 \\
(89.36)\end{array}$ & $\begin{array}{c}98773.00 \\
(88.49)\end{array}$ \\
\hline 13. & $\begin{array}{l}13 \% \text { cost managerial of } \\
\text { sub-total }\end{array}$ & $\begin{array}{c}12638.00 \\
(11.50)\end{array}$ & $\begin{array}{l}12878.00 \\
(11.50)\end{array}$ & $\begin{array}{c}13005.00 \\
(11.61)\end{array}$ & $\begin{array}{c}12840.00 \\
(11.50)\end{array}$ \\
\hline 14. & Grand total & $\begin{array}{l}109850.00 \\
(100.00)\end{array}$ & $\begin{array}{c}111943.00 \\
(100.00)\end{array}$ & $\begin{array}{l}113046.00 \\
(100.00)\end{array}$ & $\begin{array}{l}111613.00 \\
(100.00)\end{array}$ \\
\hline
\end{tabular}


Table.3 Measures of per hectare cost and profit of bottle gourd (Rs. /ha)

\begin{tabular}{|c|c|c|c|c|c|}
\hline \multirow{2}{*}{$\begin{array}{l}\text { S. } \\
\text { No. }\end{array}$} & \multirow[t]{2}{*}{ Particulars } & \multicolumn{4}{|c|}{ Measure of farm profit } \\
\hline & & $\begin{array}{l}\text { Marginal } \\
\text { below } 1 \text { ha }\end{array}$ & $\begin{array}{c}\text { Small 1-2 } \\
\text { ha }\end{array}$ & $\begin{array}{l}\text { Medium 2- } \\
\quad 4 \text { ha }\end{array}$ & $\begin{array}{c}\text { Overall } \\
\text { Average }\end{array}$ \\
\hline 1. & Cost $A_{1}$ & 40331.00 & 48351.00 & 62236.00 & 50306.00 \\
\hline 2. & Cost $B_{1}$ & 50770.00 & 54927.00 & 68849.00 & 58182.00 \\
\hline 3. & Cost $\mathrm{B}_{2}$ & 74770.00 & 79427.00 & 94149.00 & 82782.00 \\
\hline 4. & Cost $C_{1}$ & 73212.00 & 74565.00 & 74741.00 & 74173.00 \\
\hline 5. & Cost $C_{2}$ & 97212.00 & 99065.00 & 100041.00 & 98773.00 \\
\hline 6. & Cost $C_{3}$ & 109850.00 & 111943.00 & 113046.00 & 111613.00 \\
\hline 7. & Product (qt./ha) & 97.50 & 104.80 & 113.00 & 105.10 \\
\hline A & Price of Product (qt./ha) & 1750.00 & 1750.00 & 1780.00 & 1760.00 \\
\hline 8. & Gross Income & 170625.00 & 183400.00 & 201140.00 & 184976.00 \\
\hline 9. & Net return over cost $C_{1}$ & 97413.00 & 108835.00 & 126399.00 & 110803.00 \\
\hline 10 & Net return over cost $C_{2}$ & 73413.00 & 84335.00 & 101099.00 & 86203.00 \\
\hline 11. & Net income & 60775.00 & 71457.00 & 88094.00 & 73363.00 \\
\hline 12. & Family labour income & 95855.00 & 103973.00 & 106991.00 & 102194.00 \\
\hline 13. & Farm investment income & 107852.00 & 115411.00 & 133012.00 & 118679.00 \\
\hline 14 & Farm Business Income & 130294.00 & 135049.00 & 138904.00 & 134670.00 \\
\hline 15. & Cost of production (Rs./q) & 1127.00 & 1068.00 & 1001.00 & 1062.00 \\
\hline 16 & Input-Output Ratio & & & & \\
\hline $\mathrm{A}$ & On the basis of cost $A_{1}$ & $1: 4.23$ & $1: 3.79$ & $1: 3.23$ & $1: 3.67$ \\
\hline $\mathrm{B}$ & On the cost ' $\mathrm{B}_{1}$ ' basis & $1: 3.36$ & $1: 3.33$ & $1: 2.92$ & $1: 3.17$ \\
\hline $\mathrm{C}$ & On the cost ' $\mathrm{B}_{2}$ ' basis & $1: 2.28$ & $1: 2.30$ & $1: 2.13$ & $1: 2.23$ \\
\hline $\mathrm{D}$ & On the cost ' $C_{1}$ ' basis & $1: 2.33$ & $1: 2.45$ & $1: 2.69$ & $1: 2.49$ \\
\hline $\mathrm{E}$ & On the cost ' $\mathrm{C}_{2}$ ' basis & $1: 1.75$ & $1: 185$ & $1: 2.01$ & $1: 1.87$ \\
\hline $\mathrm{F}$ & On the cost ' $\mathrm{C}_{3}$ ' basis & $1: 1.55$ & $1: 1.63$ & $1: 1.77$ & $1: 1.65$ \\
\hline
\end{tabular}

Note- Figure in parentheses shows the percent to corresponding total

Input-output ratio related to cost $\mathrm{C}_{3}$ was highest on medium farms (1:1.77) followed by small farms (1:1.63), and marginal farms (1:1.55). In respect of cost $C_{2}$ input-output ratio (1:2.01) was highest on medium farms followed by small farms (1:1.85), and marginal farms (1:1.75). Cost $\mathrm{C}_{1}$ input-output ratio (1:2.69) was highest medium farms followed by small farms $(1: 2.45)$ and marginal farms 1:2.33). In respect to inputoutput ratio (1:2.30) of $\mathrm{B}_{2}$ was found highest on small farms followed by marginal farms (1:2.28) and medium farms (1:2.13) whereas, in Cost $\mathrm{B}_{1}$ the input-output ratio was highest on marginal farms (1:3.36) followed by small farms (1:3.33) and medium farms (1:2.92). In respect to cost $A_{1}$, Input-output ratio cost $A_{1}$, was highest on marginal farms (1:4.23) followed by small farms $(1: 3.79)$ and medium farms (1:3.23), respectively.
In conclusion in this study cost of cultivation profit and input output ratio were estimated using CACP cost function. Medium farms indicates that cost incurred in production is higher because of maximum investment in working capital and the he maximum share among these costs was rental value of owned land being 22.04 per cent of total cost per hectare. Costs and income of bottle gourd production per hectare average yield was calculated as 105.10 quintal per hectare and gross returns were calculated as maximum in medium farms Rs. 201140.00. BC ratio and net income found maximum in bottle gourd production in medium farm size group. Study concluded that farmers of medium category of land holding have good economic conditions due to applying timely management practices, investment in better inputs and technology. 


\section{References}

Akter, S.; Islam, M.S. and Rahman, M.S. (2011). An economic analysis of winter vegetables production in some selected areas of Narsingdi district. Department of Agricultural Economics, Bangladesh Agricultural University, 9(2): 241-246

Alam, M. K.; Idoko, M. D.; Dauna, Y. and Yengo, E, Iko, (2015). Economics of Dry Season Vegetable (Amaranthus Cruentus) Production in Jalingo Local Government Area of Taraba State, Nigeria. Department of Agricultural Extension and Management, Vol. 5, NO. 6.

Balaa, B.; Sharma, N. and Sharma, R.K. (2011). Cost and Return Structure for the Promising Enterprise of Off-Season Vegetables in Himachal Pradesh. Agricultural Economics Research Review, 24:141-148

Ibekwe, U.C. and Adesope, O.M (2010). Analysis of dry season vegetable production in Owerri West Local Government Area of Imo State, Nigeria. Department of Agricultural Economics, Federal University of Technology, University of Nigeria. Journal of Development and Agricultural Economics. 2(6): 245-249.

Joshi, P.K.; Joshi, L. and Birthal, P.S. (2006). Diversification and Its Impact on Smallholders: Evidence from a Study on Vegetable Production. Agricultural
Economics Research Review, 19: 219236.

Khatri, R.T.; Mistry, H.H. and Patel, K.S. (2010). Comparative economics of production of important vegetables in Surat district. International Research Journal of Agricultural Economics And Statistics, 2 (1): 58-6.2

Koshta, A.K. and Chandrakar, M.R. (1999). Economics of production and marketing of vegetable crop in Durg district of Chhattisgarh Region. Agricultural marketing; 42(2):28-35.

Koshta, A.K.; Chandrakar, M.R. and Agrawal, K.G. (1996). Production and marketing of progressive vegetable farms under tubewell and river irrigation situation in Raipur District of M.P. Bihar Journal of Agricultural Marketing; 4(3): 223-231.

Nair, R. and Barche, S. (2014). Protected Cultivation of Vegetables - Present Status and Future Prospects in India. 4 (6):2249-555X

Nandeshwar, J.N.S.; Pritish, T. and Kumar, S.M. (2013). Department of Agricultural Economics and Statistics, Post Graduate Institute, G.J B.A.H.S., 2(2): 78-82

Peña, R.D.L. and Hughes, J. (2007). Improving Vegetable Productivity in a Variable and Changing Climate. AVRDC - The World Vegetable Centre P.O. Box 42, Shanhua, Tainan, 74199

\section{How to cite this article:}

Krishna Kant, Tankit Kumar and Singh, J. P. 2021. Cost and Income from Bottle Gourd Production in Meerut District of Western Uttar Pradesh. Int.J.Curr.Microbiol.App.Sci. 10(02): 3017-3022. doi: https://doi.org/10.20546/ijcmas.2021.1002.330 